\title{
ANALISIS PENDAPATAN PETANI KELAPA-TERNAK SAPI DI KAWASAN AGROPOLITAN KECAMATAN TENGA KABUPATEN MINAHASA SELATAN
}

\author{
A.H.S. Salendu dan F.H. Elly*)
}

Fakultas Peternakan Universitas Sam Ratulangi Manado, 95115

\begin{abstract}
ABSTRAK
Kabupaten Minahasa Selatan merupakan daerah yang direncanakan untuk pengembangan agropolitan. Ternak sapi sebagai ternak andalan dikembangkan dengan cara digembalakan di bawah pohon kelapa. Permasalahannya seberapa besar alokasi tenaga kerja dan pendapatan kelapa-usaha ternak sapi di kecamatan Tenga. Tujuan penelitian ini untuk menganalisis alokasi tenaga kerja dan pendapatan kelapa usaha ternak sapi. Berdasarkan hasil penelitian menunjukkan bahwa kegiatan untuk pengolahan kopra yang dialokasi oleh tenaga keluarga adalah 480 jam. Sedangkan penggunaan tenaga kerja luar keluarga (sewa) adalah untuk kegiatan pengolahan kopra yaitu 1.440 jam lebih besar dari jam kerja untuk keluarga. Tenaga kerja yang digunakan untuk usaha ternak sapi adalah tenaga kerja keluarga dengan alokasinya untuk kegiatan pindahkan sapi, mencari rumput, memberi makan, minum dan memandikan sapi. Alokasi jam yang terbesar untuk pindahkan sapi. Pendapatan dari penjualan kopra tergantung dari harga kopra. Harga kopra yang dijual di tempat petani lebih rendah dibanding dijual di perusahaan minyak goreng. Rata-rata pendapatan ternak sapi sebesar $\mathrm{Rp} 1.621 .854,06$ per tahun per responden. Pendapatan ini diperoleh tanpa perhitungan tenaga kerja keluarga. Saran penelitian ini adalah perlu intervensi dari pemerintah untuk pengembangan ternak sapi karena dengan penjualan ternak sapi sejumlah 1,42 ekor dalam setahun sangat merugikan petani.
\end{abstract}

Kata Kunci : Pendapatan, kelapa, ternak sapi

*Jurusan Sosial Ekonomi Peternakan

\section{ABSTRACT}

$\begin{array}{lcr}\text { INCOME ANALYSIS OF COCONUT- } \\ \text { CATTLE } & \text { FARMER'S } & \text { IN } \\ \text { AGROPOLITAN } & & \text { AREA } \\ \text { SUBDISTRICT } & \text { TENGA } & \text { SOUTH } \\ \text { MINAHASA } & \text { REGENCY. } & \text { South }\end{array}$

Minahasa district is an area planned for agropolitan development. Cattle as a main ruminant livestock was developed by grazing method under coconut plantation. The problems are how big the allocation of labor and the income of coconut-cattle farming in the district of Tenga. The purpose of this study was to analyze the allocation of labor and income of coconutcattle farming. The result showed that the activities for the processing of copra allocated by the family labor were 480 hours. While the use of hired labor (rent) for copra processing activity were 1,440 hours greater than work allocation time for the family. Family labors used for the cattle farming were including to move the cattle for grazing and drinking, to collect grass, to feed and to cleanse animals. The largest time allocation by household family was move cattle for grazing and drinking. Income of the copra earned by haousehold family was depend on the price of copra. Price of copra earned by households at their location was lower than the price accepted at the cooking oil company. The average income of cattle household farmers was $\mathrm{Rp} \mathrm{1,621,854.06}$ per year per respondent. This income was obtained without including family labor. It was suggested in this study that the government policy was crucial for cattle development due to low sale of cattle per year with the average of 1.42 head. This case inflicted a loss upon the household farmers.

Keywords: income, coconut-cattle farmer, 


\section{PENDAHULUAN}

Secara geografis, Sulawesi Utara merupakan daerah yang sangat strategis untuk kawasan Asia Pasifik yang merupakan pintu gerbang lalu lintas keluar masuknya aneka barang perdagangan. Keadaan ini memberikan peluang pasar bagi usaha-usaha yang ada termasuk usahaternak sapi, dengan demikian ternak sapi di Sulawesi Utara mempunyai masa depan dan potensi pasar yang menggembirakan. Ternak sapi juga merupakan sumber pendapatan daerah melalui perdagangan ternak antar pulau. Ternak sapi dapat dinyatakan sebagai prime mover bagi perekonomian di Sulawesi Utara. Permasalahannya peran dan potensi usaha ternak sapi belum optimal. Hal inilah yang menyebabkan populasi ternak yang semakin menurun yang diikuti dengan penurunan produksi daging sapi serta permasalahan lain. Populasi ternak untuk Sulawesi adalah $10 \%$, dengan konsumsi sebesar $8 \%$ berarti selisih antara populasi dan konsumsi hanya 2 $\%$ (Yusdja dan Ilham, 2004 dalam Daryanto, 2007).

Penelitian tentang usaha ternak sapi di beberapa daerah menunjukkan bahwa sistem pemeliharaan ternak sapi masih ekstensif. Hal ini mengindikasikan bahwa laju pertumbuhan populasi ternak lambat yang disebabkan ternak sapi dewasa dimanfaatkan sebagai tenaga kerja. Tenaga kerja ternak sapi sebenarnya merupakan alternatif pendapatan bagi petani peternak. Menurut Santoso dan Tuherkih (2003), lambatnya perkembangan ternak sapi potong disebabkan oleh dua faktor yang bertentangan yaitu populasi ternak yang ada sedikit namun disisi lain jumlah ternak sapi yang dipotong banyak.

Kondisi ternak sapi lokal saat ini (Wijono, et al., 2003) telah mengalami degradasi produksi dan ditemukan bentuk tubuhnya yang kecil. Hal ini diakibatkan karena mutu genetik sapi lokal yang semakin menurun. Semakin baik bibit ternak sapi walaupun bibit lokal tetapi merupakan bibit hasil seleksi maka produksi dapat ditingkatkan selanjutnya pendapatan dapat meningkat.

Pemberian pakan juga mempengaruhi produktivitas ternak. Pakan yang semakin baik menyebabkan produktivitas ternak semakin meningkat. Pakan merupakan sarana produksi yang sangat penting bagi ternak karena berfungsi sebagai 
pemacu pertumbuhan. Usaha penggemukan sapi dalam hal ini tidak terbatas pada penggunaan input pakan saja. Hal yang perlu mendapat perhatian adalah perbaikan aspek pemeliharaan berupa perbaikan kandang dan pemanfaatan limbah untuk pakan. Selain itu menurut Hendayana dan Yusuf (2003), perlu upaya untuk mengantisipasi keberlanjutan usaha melalui penanaman tanaman pakan dan pembuatan hay (rumput dan jerami).

Karakteristik petani peternak selain beternak juga melakukan kegiatan pertanian seperti perkebunan (kelapa), menanam padi, palawija dan tanaman musiman lainnya. Hal yang menarik disini bahwa usaha ternak sapi yang ada di Kecamatan Tenga sampai saat ini masih dikelola secara tradisional. Permasalahan yang dihadapi peternak yang tradisional diantaranya peternak belum memperhatikan budidaya ternak baik bibit, pakan, penyakit, pengelolaan. Keberhasilan usaha ternak sapi dapat dicapai bila memperhatikan masalah breeding, feeding dan management. Permasalahan lain menurut Daryanto (2007) diantaranya lemahnya permodalan, kurangnya standar kualitas dan keamanan pangan yang berasal dari ternak sapi dan penanganan pasca panen yang belum memadai. Keadaan usaha ternak sapi yang masih tradisional tersebut dapat dinyatakan belum dapat mendukung program pemerintah untuk swasembada daging sapi pada tahun 2010 bahkan tahun 2014.

Beberapa penelitian menunjukkan bahwa usaha ternak dapat memberikan kontribusi terhadap pendapatan petani peternak. Besarnya kontribusi tergantung jenis ternak yang digunakan, cara pemeliharaan dan alokasi sumberdaya yang tersedia di masing-masing wilayah (Rao and Saxena, 1994 dalam International Center for Integreted Mountain Development (1998), Sugeha (1999), Hoda (2002), Somba (2003) dan Taufel et al., (2005).

Berdasarkan pemikiran dan kenyataan tersebut di atas, maka tantangan ke depan adalah apakah usaha ternak sapi di Kecamatan Tenga dapat memberikan kontribusi bagi pendapatan petani peternak sapi di Kawasan Agropolitan. Dalam kaitannya dengan pendapatan petani peternak maka telah dilakukan penelitian untuk menganalisis pendapatan petani kelapa-ternak sapi 
di Kawasan Agropolitan Kecamatan Tenga Kabupaten Minahasa Selatan.

Seperti yang dinyatakan Imam (2003) bahwa pola pengembangan peternakan yang dapat dikembangkan adalah diversifikasi ternak sapi dengan lahan persawahan, perkebunan dan tambak. Penelitian yang mirip dilakukan oleh Suwandi (2005) yaitu adanya penerapan pola usahatani padi sawah-sapi potong. Pengembangan usahaternak sapi dengan sistem ini dapat meningkatkan produksi dan keuntungan bagi petani dengan lahan sempit.

Usaha ternak sapi merupakan tumpuan rumahtangga pedesaan dalam peningkatan kesejahteraan mereka. Berkaitan dengan peningkatan pendapatan rumahtangga petani peternak yang selanjutnya mengarah ke peningkatan kesejahteraan maka usaha tersebut dapat dikembangkan ke arah yang lebih baik. Permasalahannya sejauhmana alokasi tenaga kerja keluarga petani dalam usaha tani kelapa-ternak sapi dan sejauhmana pendapatan petani yang diperoleh dari usaha tani kelapa-ternak sapi di Kecamatan Tenga Kabupaten Minahasa Selatan. Tujuan penelitian ini adalah untuk menganalisis alokasi tenaga kerja keluarga petani dalam usaha tani kelapa-ternak sapi dan menganalisis pendapatan petani yang diperoleh dari usaha tani kelapa-ternak sapi di Kecamatan Tenga Kabupaten Minahasa Selatan.

\section{MATERI DAN METODE PENELITIAN}

Penelitian yang telah dilakukan mengikuti langkah-langkah seperti yang dinyatakan Neuman (2000) yaitu langkah pertama: metode penelitian, kedua : pengumpulan data, ketiga : penentuan sampel, keempat: penentuan responden; dan kelima : metode analisis.

Penelitian dilakukan dengan menggunakan metode survei pada sampel petani peternak sapi di Kecamatan Tenga. Pengumpulan data dilakukan dengan menggunakan metode wawancara kepada responden petani peternak dan menggunakan kuesioner yang telah disiapkan.

Jenis data yang digunakan adalah data cross section dan data time series, dari sumber data primer dan data sekunder. Data primer (cross section setahun) diperoleh dari wawancara langsung dengan responden. Sedangkan data sekunder (time series tahunan) diperoleh dari instansi yang terkait dengan penelitian ini serta data hasil penelitian yang dipublikasi (Sinaga, 1996). 
Desa di Kecamatan Tenga ditentukan secara purposive, yaitu desa Molinow dan Sapa yang dominan usaha tani kelapa dan mempunyai jumlah ternak sapi terbanyak. Petani peternak disetiap desa sampel dibatasi untuk petani peternak yang memiliki ternak sapi minimal 2 (dua) ekor dan pernah menjual ternak sapi. Berdasarkan jumlah petani peternak sapi di setiap desa sampel ditentukan dengan metode simple random sampling (Sinaga, 1995). Tujuan penelitian dijawab dengan menggunakan analisis deskriptif.

\section{HASIL DAN PEMBAHASAN}

Karakteristik petani peternak sapi sebagai responden menyangkut umur, tingkat pendidikan petani, jumlah anggota keluarga, pemilikan ternak sapi dan penguasaan lahan kelapa. Umur merupakan salah satu faktor sosial petani yang dapat mempengaruhi keputusan dalam proses produksi. Umur petani peternak terendah adalah 25 tahun dan umur tertinggi adalah 69 tahun. Umur petani peternak terbanyak berkisar pada umur 35-44 tahun yaitu berjumlah 12 responden (31.58\%). Kisaran umur 4554 tahun merupakan urutan kedua terbanyak yaitu berjumlah 11 responden $(28,95 \%)$, kemudian kisaran umur 25-34 tahun yaitu berjumlah 7 responden $(18,42 \%)$, kirasan umur 5564 berjumlah 6 responden $(15,79 \%)$ dan kisaran umur 65-74 tahun adalah yang terkeci yaitu 5,26\% (2 responden). Berdasarkan hasil penelitian menunjukkan bahwa sebagian besar responden dikategorikan dalam umur produktif. Kondisi ini sebagai salah satu penunjang pengembangan peternakan sapi. Kiswanto et al (2004) mengemukakan bahwa umur merupakan salah satu faktor yang dapat mempengaruhi produktivitas usaha penggemukan sapi potong.

Tingkat pendidikan petani peternak sebagai kepala keluarga di wilayah penelitian mulai dari tidak tamat SD sampai dengan Perguruan Tinggi, dengan rata-rata lama pendidikan sebesar 7,18 tahun. Sebagian besar petani peternak sebagai responden berpendidikan SD (tamat) yaitu berjumlah 18 responden $(47,37 \%)$. Petani peternak yang tidak tamat SD merupakan urutan kedua yaitu masing-masing berjumlah 10 responden $(26,31 \%)$, kemudian diikuti dengan tingkat pendidikan SLTA (tamat) berjumlah 6 responden $(15,79 \%)$ dan SLTA (tamat) berjumlah 
4 responden $(10,58 \%)$. Data ini menunjukkan bahwa rata-rata tingkat petani di wilayah penelitian masih dikategorikan sangat rendah. Kondisi tersebut sangat mempengaruhi pola pikir petani peternak dalam melakukan pengembangan usaha ternak sapi kearah yang lebih baik. Semakin tinggi tingkat pendidikan maka petani peternak akan lebih mudah menyerap inovasi teknologi. Kiswanto et al (2004) mengemukakan bahwa tingkat pendidikan yang makin tinggi memungkinkan dapat mengubah sikap dan perilakunya untuk bertindak lebih rasional.

Pekerjaan utama responden sebagian besar adalah petani (on farm) yaitu berjumlah 21 responden $(55,27$ $\%)$, kemudian diikuti oleh buruh tani (off farm) yaitu berjumlah 11 responden $(28,95 \%)$. Pekerjaan petani peternak bukan usahatani (non farm) yaitu terdiri dari pedagang berjumlah 3 responden $(7,89 \%)$, pegawai swasta/pensiunan 2 responden $(5,26 \%)$ dan nelayan 1 responden $(2,63 \%)$. Kondisi pekerjaan utama sebagai petani menunjukkan pengalaman petani dalam melakukan proses produksi usahatani.

Hasil penelitian menunjukkan bahwa sebagian besar petani peternak sebagai responden berstatus sebagai pemilik lahan yaitu berjumlah 18 responden $(47,37 \%)$. Sedangkan petani peternak sebagai peminjam berjumlah 13 responden $(34,21 \%)$ dan petani penggarap kelapa berjumlah 7 responden $(18,42 \%)$. Kondisi ini menunjukkan bahwa walaupun petani tidak memiliki lahan kelapa tetapi mereka memanfaatkan lahan kelapa milik orang lain atau milik perusahaan perkebunan untuk pengembangan usaha ternak sapi. Ternak sapi digembalakan di bawah pohon kelapa dan dipindah-pindah dari lahan yang satu ke lahan lainnya.

Luas pemilikan lahan bervariasi, demikian pula luas lahan garapan dan lahan yang dipinjam bervariasi yaitu sekitar 0,5-10 ha. Total luas lahan kelapa milik petani, luas lahan yang digarap dan dipinjam sebesar 67 ha atau rata-rata 1,76 ha. Luas pemilikan lahan milik sendiri 31,60 ha atau ratarata 1,66 ha per responden pemilik, luas lahan yang digarap 24,20 ha atau rata-rata 3,46 ha (rata-rata yang terbesar) per responden penggarap dan luas lahan yang dipinjam 11,20 ha atau rata-rata 0,93 ha per responden peminjam. Kondisi ini menunjukkan bahwa lahan di bawah pohon kelapa milik petani yang dimanfaatkan untuk 
ternak sapi cukup luas. Tetapi ternak sapi hanya mengkonsumsi limbah pertanian dan rumput liar yang tumbuh di bawah pohon kelapa tersebut.

Jumlah pohon kelapa berkisar antara 30 - 1000 pohon dengan total keseluruhan 6.341 pohon atau rata-rata 166,87 pohon per responden. Lahan kelapa yang dikelola baik oleh pemilik penggarap maupun peminjam berjumlah 6.341 pohon. Jumlah pohon kelapa yang dikelola oleh pemiliknya sebanyak 2.781 pohon atau 154,50 pohon per responden. Lahan yang dipinjam untuk penggembalaan ternak sapi berjumlah 1.150 pohon atau ratarata 344,29 pohon kelapa dan yang dikelola oleh petani peternak sapi sebagai penggarap berjumlah 2.410 pohon atau rata-rata 344,29 pohon per responden.

Hasil kelapa dipanen tiap 3 bulan (satu tahun 4 kali panen). Tetapi sebagian petani peternak sapi melakukan panen kelapa setiap 4 bulan sekali (dalam satu tahun 3 kali panen). Buah kelapa sesuai hasil penelitian diolah menjadi kopra. Produksi buah kelapa per pohon sekitar 20-40 buah. Kopra 100 kg yang dihasilkan membutuhkan 400-450 buah kelapa, tergantung besarnya buah kelapa. Besarnya buah kelapa tergantung daerah, daerah yang lebih dekat pantai buahnya lebih besar (informasi dari petani kelapa).

Penggunaan tenaga kerja untuk mengolah kopra adalah penggunaan tenaga kerja keluarga dan luar keluarga (sewa). Alokasi jam kerja untuk pengolahan kopra paling besar yaitu 480 jam atau rata-rata 19,32 jam/kwartal. Buah kelapa diolah menjadi kopra membutuhkan waktu sekitar 2-3 hari untuk memanggang buah kelapa tersebut. Alokasi jam kerja untuk kupas kelapa merupakan urutan kedua terbesar yaitu 108 jam/kwartal atau 2,84 jam/kwartal/responden. Alokasi waktu untuk kupas kelapa lebih banyak dilakukan sendiri oleh petani. Angkut kelapa merupakan urutan ketiga yaitu 83 jam/kwartal atau 2,18 jam per kwartal per responden, hal ini disebabkan karena sebagian petani memiliki gerobak yang digunakan untuk mengangkut kelapa. Petani menggunakan jam kerja keluarga untuk panjat tetapi hanya sekitar 6 jam atau rata-rata 0,16 per responden karena pekerjaan memanjat kelapa membutuhkan keterampilan khusus dan berisiko tinggi. Sebagian besar petani dalam hal ini memanfaatkan 
tenaga kerja luar (sewa) yang memiliki keterampilan dalam memanjat kelapa.

Penggunaan tenaga kerja sewa yang terbesar untuk pengolahan kopra yaitu sekitar 1.440 jam per kwartal $\begin{array}{lll}\text { atau } & \text { rata-rata }\end{array}$ jam/kwartal/responden. Penggunaan tenaga kerja sewa untuk pengolahan kopra jauh lebih besar dibanding alokasi tenaga kerja keluarga. Hal ini disebabkan pengolahan kopra oleh tenaga sewa dengan sistem pembayaran bagi hasil. Pekerjaan mengolah kopra juga membutuhkan keterampilan dan waktu yang digunakan untuk pekerjaan tersebut cukup lama.

Pembayaran upah untuk panjat kelapa dan angkut buah dilakukan dengan sistem bagi hasil yaitu 1/10 dari hasil selama satu kwartal. Sedangkan upah untuk pengolahan kopra sebagian petani menggunakan sistem $1 / 2$ atau $2 / 3$ untuk pemilik. Ada juga petani yang membayar sewa hari dan sebagian kecil petani mengerjakan sendiri (menggunakan tenaga kerja keluarga). Pembagian hasil tergantung lokasi perkebunan kelapa. Semakin tinggi tingkat kesulitan untuk pengolahan kelapa maka semakin kecil bagian yang diperoleh petani pemilik. Petani peternak yang berstatus sebagai pemilik lahan kelapa sebanyak 18 responden. Sistem pengupahan bagi hasil 2/3 untuk pemilik adalah sistem yang paling banyak dilakukan oleh petani peternak yaitu sebesar 12 responden $(66,66 \%)$. Sisanya sistem sewa panjat pohon oleh 3 responden (16,66\%), bagi hasil $1 \frac{1}{2}$ masing-masing untuk pemilik dan pekerja, sewa harian, menggunakan tenaga kerja keluarga masing-masing dilakukan oleh 1 responden $(5,56 \%)$.

Biaya tenaga kerja yang terbesar adalah biaya untuk pengolahan kopra yaitu sebesar 97,71 $\%$, sedangkan biaya panjat kelapa hanya 2,29 \%. Biaya pengolahan kopra sudah termasuk biaya angkut kelapa, kumpul kelapa dan kupas kelapa.

Hasil penelitian menunjukkan bahwa harga kopra yang berlaku di wilayah penelitian adalah berkisar antara Rp 570.000 sampai dengan Rp 980.000 per 100 kg kopra. Harga kopra tersebut berlaku bila petani peternak menjual kopranya di wilayah penelitian berbeda dengan harga kopra bila petani menjual di pabrik minyak goreng. Harga kopra akan semakin tinggi apabila petani sebagai responden menjual di pabrik minyak yang ada di Kabupaten Minahasa Selatan. Perbedaan ini tentu saja sangat 
mempengaruhi pendapatan petani peternak sapi sebagai responden. Pendapatan usahatani kelapa yang diperoleh petani peternak sapi sebagai responden adalah sebesar $\mathrm{Rp}$ 9.127.412,20 per tahun per responden. Besarnya pendapatan tergantung pada harga jual kopra, untuk biaya tenaga kerja relatif tidak bervariasi.

Sistem pemeliharaan ternak sapi sesuai hasil penelitian menunjukkan bahwa $100 \%$ ternaknya diikat/digembalakan di bawah pohon kelapa. Ternak dipindah-pindah di sekitar lahan di bawah pohon kelapa yang dimiliki, digarap ataupun dipinjam oleh petani peternak sebagai responden. Pada saat musim kemarau panjang petani peternak memotong rumput untuk dikonsumsi oleh ternaknya. Ternak sapi mengkonsumsi jerami jagung, jerami padi, rumput australia, rumput lapang, rumput gajah dan rumput lainnya dalam memenuhi kebutuhan hidupnya.

Hasil penelitian menunjukkan konsumsi tertinggi adalah untuk limbah jagung yaitu sekitar 58,76\% dari konsumsi rumput per ekor/hari. Konsumsi rumput kedua terbanyak adalah rumput lapangan yaitu sebesar $18,43 \%$ dari total konsumsi rumput per ekor per hari. Rumput lain yang dikonsumsi adalah rumput australia $(10,59 \%)$, rumput gajah $(6,01 \%)$ dan rumput lainnya $(6,21 \%)$. Rata-rata konsumsi rumput sebesar 15,26 kg/ekor/hari. Konsumsi ini belum sesuai dengan yang dianjurkan yaitu konsumsi rumput sebesar $10 \%$ dari berat badan ternak sapi, sehingga produktivitas ternak sapi rendah.

Biaya pakan merupakan biaya terbesar yaitu 99,78\% dari total biaya dan biaya obat-obatan adalah yang paling kecil yaitu 0,22\%. Perhitungan biaya di atas tanpa perhitungan biaya tenaga kerja, karena tenaga kerja yang digunakan adalah biaya tenaga kerja keluarga. Biaya pakan dan biaya obatobatan dihitung berdasarkan jumlah ternak sapi yang terjual dengan asumsi : (1) jumlah konsumsi rumput rata-rata 15,26 kg/ekor/hari; (2) harga pakan diasumsikan Rp 1000 per kg; (3) biaya obat-obatan dikonversi dari biaya obatobatan ternak sapi yang hidup.

Ternak sapi yang terjual sejumlah 68 ekor atau rata-rata 1.42 ekor. Penjualan ternak sapi dilakukan di pasar blantik (di desa Ongkaw), atau pedagang yang datang di lokasi peternak dan ada yang dijual kepada petani lain. Harga tergantung pada harga daging sapi yaitu sekitar Rp 50.000-Rp 70.000 per kg daging. Rata- 
rata pendapatan usaha ternak yang diperoleh adalah sebesar $\mathrm{Rp}$ 1.621.854,06 per tahun per responden. Pendapatan yang diperoleh ini dianggap sangat rendah dibanding hasil penelitian Rundengan (2008).

Tenaga kerja yang dialokasikan untuk usaha ternak sapi merupakan tenaga kerja keluarga. Hal ini disebabkan karena usaha ternak sapi di wilayah penelitian hanya merupakan usaha sambilan sehingga mereka tidak menyewa tenaga kerja. Tenaga kerja keluarga untuk usaha ternak sapi dialokasikan untuk kegiatan memindahkan sapi, mencari rumput, memberi makan, memberi minum dan memandikan ternak sapi. Jam kerja yang dialokasikan untuk memindahkan ternak adalah paling besar yaitu 18,50 jam per hari. Hal ini disebabkan dalam sehari petani peternak sapi memindahkan ternaknya 2-3 kali. Apabila diasumsikan upah tenaga kerja Rp 7.500 per jam maka biaya tenaga kerja per tahunnya sebesar Rp $175.555 .875,-$ atau rata-rata sebesar $\mathrm{Rp}$ 3.657.414,06 per responden per tahun. Biaya tenaga kerja ini adalah biaya yang digunakan untuk memelihara ternak sapi sebanyak 177 ekor (jumlah ternak sapi saat penelitian). Biaya tenaga kerja untuk pemeliharaan ternak sapi yang terjual (68 ekor) setahun sebelum penelitian adalah $\mathrm{Rp}$ 77.946.206,25 per tahun atau rata-rata Rp 1.623.879,30 per tahun per responden.

Hasil penelitian menunjukkan bahwa ternak sapi dimanfaatkan sebagai tenaga kerja untuk lahan sendiri ataupun disewa oleh petani lain. Tenaga kerja ternak sapi dialokasikan untuk angkut kelapa milik sendiri, bajak dan disewa oleh petani lain. Jam kerja tenaga kerja ternak sapi yang terbesar adalah jam kerja untuk disewa petani lain, yaitu sebesar 90,15 $\%$ dari kegiatan tenaga kerja ternak sapi. Kondisi ini mengindikasikan bahwa tenaga ternak sapi merupakan alternatif pendapatan bari petani peternak sebagai responden apabila ternak tersebut disewa oleh orang lain. Pendapatan dari tenaga kerja ternak sapi yang disewa orang lain di wilayah penelitian adalah sebesar $\mathrm{Rp}$ 93.920.000/tahun atau rata-rata $\mathrm{Rp}$ 2.471.578,95/tahun/responden.

\section{KESIMPULAN}

Berdasarkan hasil penelitian dapat disimpulkan bahwa alokasi tenaga kerja luar keluarga dalam usaha perkebunan kelapa untuk kegiatan pengolahan kopra lebih besar (1440 
jam per tahun) lebih besar dibanding alokasi tenaga kerja keluarga (480 jam per tahun).

Tenaga kerja untuk usaha ternak sapi adalah tenaga kerja keluarga dengan alokasinya untuk kegiatan pindahkan sapi, mencari rumput, memberi makan, minum dan memandikan sapi. Alokasi jam yang terbesar untuk pindahkan sapi.

Harga kopra yang dijual di tempat petani lebih rendah dibanding dijual di perusahaan minyak goreng. Rata-rata pendapatan ternak sapi sebesar Rp 1.621.854,06 per tahun per responden, tanpa perhitungan tenaga kerja keluarga.

\section{SARAN}

Saran penelitian ini adalah perlu intervensi pemerintah untuk pengembangan ternak sapi karena dengan penjualan ternak sapi sejumlah 1,42 ekor dalam setahun sangat merugikan petani.

\section{DAFTAR PUSTAKA}

Daryanto, A. 2007. Peningkatan Daya Saing Industri Peternakan. PT Permata Wacana Lestari. Penerbit Majalah Trobos, Jakarta.
Hendayana, R dan Yusuf. 2003. Kajian Adopsi Tehnologi Penggemukan Sapi Potong Mendukung Pengembangan Agribisnis Peternakan Di Nusa Tenggara Timur. Prosiding. Seminar Nasional Teknologi Peternakan dan Veteriner, Bogor.

Hoda, A. 2002. Potensi Pengembangan Sapi Potong Pola Usaha Tani Terpadu Di Wilayah Maluku Utara. Tesis Magister Sains. Program Pascasarjana Institut Pertanian Bogor, Bogor.

Imam, H.M.S. 2003. Strategi Usaha Pengembangan Peternakan Berkesinambungan. Prosiding. Seminar Nasional Teknologi Peternakan dan Veteriner. Bogor.

Kiswanto., A. Prabowo dan Widyantoro. 2004. Transformasi struktur Usaha Penggemukan Sapi Potong di Lampung Tengah. Sistem dan Kelembagaan Usahatani Tanaman-Ternak. Prosiding Seminar. Balai Penelitian dan Pengembangan Pertanian Departemen Pertanian. p:111121. 
Neuman, W.L. 2000. Social Research Methods. Qualitative and Quantitative Approaches. Fourth Edition. Allyn and Bacon, Singapore.

Rao and Saxena. 1994. In : International Center For Integreted Mountain Development. 1989. Livestock Development in Mixed Crop Farming System. Issues in Mountain Development. http://international center for integrated mountain development.

Rundengan, M. 2008. Analisis Pengaruh Penerimaan Terhadap Produksi Sapi di Desa Lolayan. Jurnal Zootek Vol 27, Juli 2008, p : 168-178

Santoso, D and E. Tuherkih. 2003.

$\begin{array}{lr}\text { Meningkatkan } & \text { Pengelolaan } \\ \text { Lahan Untuk } & \text { Memacu } \\ \text { Pengembangan } & \text { Ternak } \\ \text { Ruminansia. } & \text { Prosiding. } \\ \text { Seminar Nasional } & \text { Teknologi } \\ \text { Peternakan dan } & \text { Veteriner, } \\ \text { Bogor. } & \end{array}$

Sinaga, B.M. 1995. Metode Sampling.

$\begin{array}{llr}\text { Makalah Disampaikan } & \text { pada } \\ \text { Penataran Dosen- } & \text { Dosen } \\ \text { Perguruan Tinggi } & \text { Swasta. } \\ \text { Materi Metodologi } & \text { Penelitian }\end{array}$

Sosial Ekonomi di Cisarua, Bogor 19-23 Juni 1995. Direktorat Perguruan Tinggi Swasta, Direktorat Jenderal Perguruan Tinggi, Departemen Pendidikan dan Kebudayaan, Jakarta.

Sinaga, B.M. 1996. Metode Pengumpulan Data. Makalah Disampaikan pada Pelatihan Singkat Metodologi dan Manajemen Penelitian Bidang Pertanian, Cisarua Bogor 16-23 Desember 1996. Proyek Pengembangan Sebelas Lembaga Pendidikan Tinggi Bekerjasama dengan Institut Pertanian Bogor, Bogor.

Somba, S.S. 2003. Strategi Pengembangan Ternak Sapi Di Desa Kanonang II Kecamatan Kawangkoan. Skripsi. Fakultas Peternakan. Universitas Sam Ratulangi, Manado.

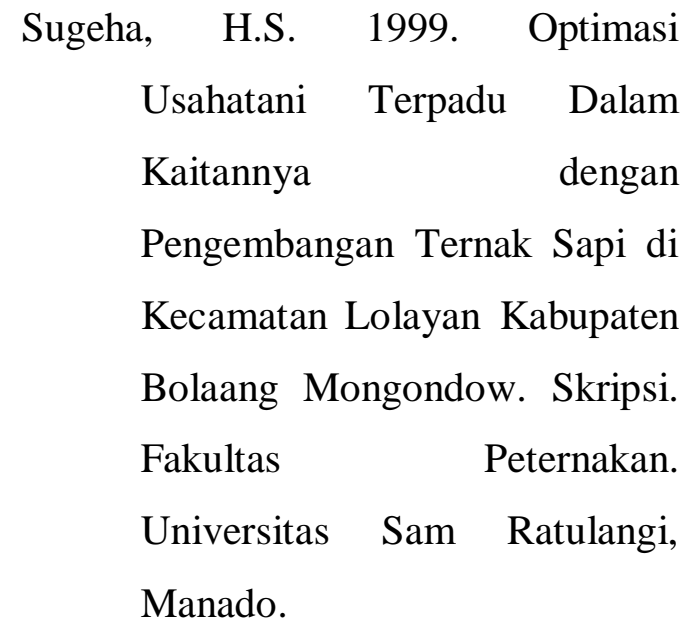


Suwandi. 2005. Keberlanjutan Usahatani terpadu Pola Padi Sawah-Sapi Potong Terpadu Di Kabupaten Sragen : Pendekatan RAP-CLS. Disertasi Doktor. Program Pascasarjana Institut Pertanian Bogor, Bogor.

Taufel, N; K. Kuettner and C. Gall. 2005. Contribution of Goat Husbandry to Household Income in the Punjab: A Review. University of Hohenheim In : Small Ruminant Research, Band 28 Helf 2. http://Contribution of Goat Husbandry to Household (30-7-2005).

Wijono, D.B., D.E. Wahyono., P.W. Prihandini., A.R. Siregar., B. Setiadi dan L. Affandhy. 2003. Performans Sapi Peranakan Ongole Muda Pascacreening. Prosiding. Seminar Nasional Teknologi Peternakan dan Veteriner, Bogor. 
